\title{
Evaluation of Operational Performance - A Case Study on Summit Power Limited (SPL)
}

\author{
${ }^{1}$ Md. Amin Mia, Md. Shamsu Uddin ${ }^{2}$, Md. Asad Iqbal Chowdhury ${ }^{3}$ \\ ${ }^{1}$ Lecturer, Department of Finance, Bangladesh University of Business \& Technology (BUBT). \\ Dhaka Commerce College Road, Mirpur-2, Dhaka-1216. \\ ${ }^{2}$ Lecturer, Department of Business Administration, Metropolitan University. Al-Hamra, Zindabazar, Sylhet- \\ 3100. \\ ${ }^{3}$ Senior Officer, Eastern Bank Limited, Head Office, Dilkusha, Dhaka.
}

\begin{abstract}
Evaluating performance through ratio analysis is a sin-qua-non for sustainable growth and measuring future risk of liquidation of a manufacturing company. The current study is an attempt to evaluate the status of the financial performance of Summit Power Limited (SPL) through liquidity, profitability and productivity position of SPL. The study found that the financial performance in terms of liquidity and profitability is considered to be above satisfactory level. In case of activity ratio accounts receivables turnover indicates satisfactory which means the policy and management for collecting credit from customers is efficient. Inventory turnover ratio indicates the worse that means the stock is not rapidly turned over. Total asset turnover ratio is not satisfactory which means inefficient utilization of investment in generating more revenue. The study also depicted that SPL's long term solvency position in terms of debt to total asset ratio was not satisfactory which means SPL carried higher debt and had been incurring a heavy burden of interest and risk during 2004 to 2012. The value of $Z$ also indicates the financial soundness and less risk of bankruptcy of SPL. The study suggest some policy implications for future growth and development of SPL like; introduction of modern technologies and research and development, modern marketing techniques to boost up revenue, suitable pricing policy and the like.
\end{abstract}

Key words: Solvency, Profitability, Asset-management, Productivity, Z score, Balanced Score Card.

\section{Statement of the Problem:}

The demand of electricity both in rural and urban area is increasing day by day. Considering the immense opportunities, the SPL is striving to establish more power plants around the country. The fast-growing company has set a mission to expand the company with a power generation capacity to the tune of $1000 \mathrm{MW}$, which is a modest $20 \%$ of the electricity requirement in Bangladesh. Summit Power Limited (SPL), sponsored by Summit Group, is the first Bangladeshi Independent Power Producer (IPP) in Bangladesh in private sector providing power to national grid. SPL was incorporated in Bangladesh on March 30, 1997 as a Private Limited Company. On June 7, 2004 the Company was converted to Public Limited Company under the Companies Act 1994. SPL has two major challenges, first keeping price level reasonable for the people and second to ensure long term sustainability of the corporation. But it's performance both in terms of financial and operational are very pitiable since its starting period. The situation is still valid. At this stage it is essential to analysis the performance of SPL to find out main causes thereof. For the sustainable growth and development of a firm an efficient performance evaluation is essential. Performance evaluation means first measures and evaluates the results and then sort out the efficiency, liquidity, profitability, strength and weakness for the continuous improvement of performance. In a efficient performance evaluation includes all aspects of an enterprise. With the advance of computation tools, performance evaluation systems now can cover all aspects of performance. The present study is an endeavor to evaluate the operational performance of SPL by applying the techniques of financial analysis. Financial analysis includes the analysis of balance sheet, profit and loss account and the other financial statement of the company.

\section{Literature review:}

Tarawneh (2006) made an evaluation of financial performance in the banking sector in Bangladesh by the financial ratios and hypothesis test. He found that the bank with higher total capital, deposits, credits or total assets does not always mean that has better profitability performance.

Masum and johora(2012) applied ratio analysis, standard deviation and Multivariate discriminate model to evaluate the performance of ceramic industry of Bangladesh and tested its financial soundness. They depicted that the financial position and operational performance of the selected ceramic companies in terms of profitability and efficiency is good and suggested due to inefficient liquidity management and lack of proper utilization of debt financing it showed very low performance.Salauddin(2001) exercised ratio analysis, mean, 
standard deviation and coefficient of variation to analyze the profitability of the pharmaceutical companies of Bangladesh and found in terms of standard norms of return on the investment of pharmaceutical sector was satisfactory at the study period. Jahur and mohiuddin(1995) used financial ratios to find out profitability, activity, liquidity position as well as overall operational performance of a limited company. Jahur and parveen (1996) applied Altman's MDA model to determine overall financial position of Chittagong Still Mills Ltd and found the position of the mill had been at the lowest level of bankruptcy. They concluded scarcity of raw materials, lack of adequate working capital, strict government regulation, lack of accountability etc. were main reasons of failure.

In the article "Bank performance analysis: Methodology and empirical evidence (Estonian Banking System, 1994-2002) Arama, Vainu, Vensel used a modified version of du-pond financial ratio and a novel matrix approach for the performance evaluation of commercial banking system. They found the rise of the Estonian commercial Banking system performance efficiency which revealed in the increase of the rate of return indicator such as ROA and ROE. Taslim (2013) used financial ratios to denote profitability, activity and solvency of a limited company.

\section{Objectives of the study:}

The Prime objective of the study is to critically analyze the operational performance of Summit Power Limited (SPL). To achieve this prime objective the study has covered the following specific objectives:

a. To examine the short term solvency of SPL

b. To examine the long term solvency of SPL

c. To examine the asset management position of SPL

d. To evaluate the profitability position of SPL.

e. To measure the productivity position of SPL.

f. To highlight the non-financial performance through Balanced Score Card Model.

g. To find out problems and suggest some policy implications for the improvement of performance of SPL.

\section{Scope and methodology of the study:}

The present study is based on secondary data collected from the audited profit and loss account, balance sheet of SPL for the period of 9 years (2004-2012), existing text books, related journals and magazines and research work have been checked to prepare the theoretical framework of the study. In order to analyze financial performance in terms of liquidity, solvency, profitability and financial efficiency various accounting ratios have been used.

\section{Analyzing financial performance: key ratio forms}

Performance evaluation means evaluating or measuring something's in order to ensure that it's behave well or executed normally(jahur \& Uddin, 1995). Financial performance of a company can be analyzed by various measures of which, the important one is known as ratio analysis. It is defined as the systematic use of ratio to interpret financial statements so that the strength and weakness of a firm as well as its historical performance and current financial condition can be determined (wiki. answer, 2009)

\section{1 Examination of short term solvency position of MPL.}

\section{Findings and their analysis:}

Liquidity ratios are used to measure the ability of a firm to meet its short term obligations and reflected short term financial strength. Evaluations of liquidity enable financial management to keep a balance liquidity position for satisfying all the promises made by the company and ensure short term solvency. Current ratio and quick ratio, cash ratio are common liquidity ratio used to measure the liquidity status, movement of fund, idle fund (if any) of an enterprise. Current ratio indicates a firm's liquidity position and short term solvency. If the ratio is too low, the firm may face liquidity crisis. If the ratio is too high, the firm may have excess investment in current assets. An ideal current ratio is 2:1. Quick test measure the ability of the company to pay its creditors in the short term from its most liquid assets. Against this back drop, the following table shows the position of short term solvency of SPL of the selected years.

Table-1 Position of current ratio and Quick ratio of SPL during the period 2006 to 2012

\begin{tabular}{|l|c|c|c|c|c|c|c|c|c|c|c|c|}
\hline & 2004 & 2005 & 2006 & 2007 & 2008 & 2009 & 2010 & 2011 & 2012 & Mean & SD & CV \\
\hline $\begin{array}{l}\text { Current } \\
\text { ratio }\end{array}$ & 0.76 & 1.87 & 0.39 & 0.53 & 0.70 & 0.90 & 9.70 & 2.10 & 5.82 & 2.53 & 3.18 & 1.25 \\
\hline $\begin{array}{l}\text { Quick } \\
\text { ratio }\end{array}$ & 0.43 & 1.63 & 0.22 & 0.34 & 0.50 & 0.66 & 8.79 & 1.62 & 5.11 & 2.14 & 2.92 & 1.36 \\
\hline
\end{tabular}

Source: annual reports of SPL for the years from 2004 to 2012 and computations have been made by the researchers. 
It is found from the above table- 1 the current ratio of SPL were $0.76,1.87,0.39,0.53,0.70,0.90,9.70$, 2.10 , and 5.82 during the study period and on an average it was 2.53 which is above the standard norm of 2:1( Bhattacharya and Roy,1999). The current ratio shows the fluctuating trend during the study period and it implies that in some years SPL was able to pay its short term obligation and in some years SPL was not able to pay its short term obligation. It is also seen that the quick ratios of SPL were $0.43,1.63,022,0.34,0.50,0.66,8.79$, 1.62 and 5.11 during study period respectively and on an average 2.14 which was above the standard norm of 1:1(Moshin,1970). It indicates that, on a average SPL has a strong position to pay its most immediate liquidity. From the analysis it can be conclude that SPL is able to meet the short term obligation satisfactorily.

\section{2 Examination of long term solvency position of SPL}

For measuring the long term financial position of the firm, solvency ratios are calculated. Solvency ratio measures the long term solvency of a firm which includes determining the ability to repay principal amount of its debt, pay interest on borrowing and to meet other financial obligation. They also give insight into the capital structure of the firm i.e. the mix of equity and debt. Financial health of the company can be drawn through using different solvency ratios named debt to total assets, time interest earned and fixed charge coverage ratio. Debt to Equity ratio shows the extent to which debt financing has been used in the business. A high ratio shows that the claims of creditors are greater than those of owners. A lower ratio implies a greater claim of owner than creditors. Debt to total asset ratio equals to total debt divided by total equities. Generally, creditors prefer a low debt to total asset ratio since it implies a greater protection of their position. Time interest earned ratio measures the number of times the interest payable is covered by profit available for such payments. It can be calculated dividing earnings before interest and tax by the interest changes. Some authors consider 8 times of time interest earned as standard norm for any company. The following table shows the position in the regard:

Table-2 Position of Debt to equity ratio and time interest earned ratio of SPL during the period 2004 to2012

\begin{tabular}{|l|c|c|c|c|c|c|c|c|c|c|c|c|}
\hline & 2004 & 2005 & 2006 & 2007 & 2008 & 2009 & 2010 & 2011 & 2012 & Mean & SD & CV \\
\hline $\begin{array}{l}\text { Debt to } \\
\text { Equity } \\
\text { ratio }\end{array}$ & 0.81 & 0.52 & 1.41 & 1.90 & 0.63 & 0.42 & 0.85 & 0.26 & 0.18 & 0.78 & 0.56 & 0.72 \\
\hline $\begin{array}{l}\text { Debt to } \\
\text { total asset } \\
\text { ratio }\end{array}$ & 0.45 & 0.34 & 0.59 & 0.66 & 0.39 & 0.29 & 0.80 & 0.22 & 0.15 & 0.43 & 0.21 & 0.49 \\
\hline $\begin{array}{l}\text { Times } \\
\text { interest } \\
\text { earned }\end{array}$ & 3.75 & 4.37 & 4.46 & 1.39 & 2.44 & 3.02 & 6.64 & 29.90 & 4.10 & 6.68 & 8.83 & 1.32 \\
\hline
\end{tabular}

Source: - annual reports of SPL for the years from 2004 to 2012 and computations have been made by the researchers.

Table-2 revealed that the average Debt to Equity ratio was 0.78 which is below the standard norm of (a) 65:35 prescribed by the Bangladesh Shipla Rin Sangstha for its project appraisal (Houque, 1987). (b) 50:50 prescribe by the controller of capital issue, Bangladesh (c) 58:42, observed in selected electricity generation and Supply Company in India. This proves that SPL is not a geared corporation. The average debt to total asset ratio was 0.43 which was higher than the standard norm of 0.35 (Banerjee,1984). It explains that the SPL carried higher debt and had been incurring a heavy burden of interest and risk during 2004 to 2012 .

\subsection{Analysis of asset management position of SPL}

Activity ratios are also known as asset management ratios, efficiency ratios or turnover ratios which indicates the ability to translate its' assets into sales. Inventory turnover, Total assets turnover, and Account Receivable turnover ratio are the commonly used as activity ratios. Account receivable turnover has been computed by dividing net credit sale by closing average receivable. This ratio measures how quick the firm collects their due from their customers. It provides a clear concept credit sale and collection policy. Some authors consider 4 times of account receivable turnover as the reasonable norm. Inventory turnover depicts the relationship between cost of goods sold and the total inventory. Some authors consider 8-9 times of Inventory turnover as standard norm. A low inventory turnover indicates firm has excessive investment in inventory \& high ratio often means that the firm is running out of stock. Total assets turnover measures the extent of generating sales in terms of the total assets. 2 times is considered as standard norm of this ratio. The following table shows the asset management position of the selected firm: 
Table-3 Position of Debt Account receivable turnover, Inventory turnover and Total assets turnover of SPL during the period 2006 to 2012

\begin{tabular}{|c|c|c|c|c|c|c|c|c|c|c|c|c|}
\hline & 2004 & 2005 & 2006 & 2007 & 2008 & 2009 & 2010 & 2011 & 2012 & Mean & SD & $\mathrm{CV}$ \\
\hline $\begin{array}{l}\text { Accounts } \\
\text { Receivables } \\
\text { turnover }\end{array}$ & 11.70 & 10.85 & 6.32 & 6.09 & 8.59 & 10.13 & 2.03 & 1.89 & 2.38 & 6.66 & 3.90 & 0.59 \\
\hline $\begin{array}{l}\text { Inventory } \\
\text { turnover }\end{array}$ & 5.07 & 4.82 & 2.45 & 3.31 & 4.60 & 4.85 & 7.57 & 1.86 & 1.98 & 4.06 & 1.84 & 0.45 \\
\hline $\begin{array}{l}\text { Total assets } \\
\text { turnover }\end{array}$ & 0.53 & 0.33 & 0.21 & 0.28 & 0.31 & 0.30 & 0.21 & 0.16 & 0.21 & 0.28 & 0.11 & 0.38 \\
\hline
\end{tabular}

Source: - annual reports of SPL for the years from 2004 to 2012 and computations have been made by the researchers

The above table- 3 reveals that the accounts receivables turnover of SPL was $11.70,10.85,6.32,6.09$, $8.59,10.13,2.03$ and 2.38 and on an average it was 6.66 times which is more than the standard norm of 4 times (Ibid). It implies that has the policy and management for collecting credit from customers is efficient. The inventory turnover of SPL was 5.07, 4.82, 2.45, 3.31, 4.60, 4.85, 7.57, 1.86 and 1.98 and on an average it was 4.06 times which less than the standard norm of 8 times (Ibid). The inventory turnover on an average during the period under study was 4.06 times which less than the standard norm was 8 to 9 times (Moshin, 1970). Lower the ratio the worse because it means the stock is not rapidly turned over. The total asset turnover was $0.53,0.33$, $0.21,0.28,0.31,0.30,0.21,0.16$ and 0.21 during the study period 2004 to 2012 respectively and in an average it was 0.28 times which less than the standard norm 2 times(Weston and Brigham-2004). It indicates that SPL Generated lower taka of sales per taka of tangible assets which may be an indication of inefficient use of fixed and circulating capital.

\subsection{Profitability as a yardstick for Evaluation:}

The profitability ratio measures the efficiency of generating profit of a firm. Profitability ratios are generally satisfied the questions of different users such as (1) what is the rate of profit? (2) Is the profit earned by the company adequate? (3) What is EPS? (4) What is the dividend pay out ratio? (5) What is the rate of return to fund invested by the shareholder? So on (khan and jain, 2004).since, profit is the ultimate objective of the firm, poor performance here indicates a basic failure. To determine different aspects related with the profitability of the firm various ratios are calculated like- Gross profit margin, Net profit margin, operating income margin, return on assets and return on equity ratio the following table depicts the profitability position of the selected firm:

Table-4 Profitability position of SPL from the period 2006 to 2012

\begin{tabular}{|c|c|c|c|c|c|c|c|c|c|c|c|c|}
\hline & 2004 & 2005 & 2006 & 2007 & 2008 & 2009 & 2010 & 2011 & 2012 & Mean & SD & $\mathrm{CV}$ \\
\hline $\begin{array}{l}\text { Gross profit } \\
\text { margin }(\%)\end{array}$ & 51.57 & 54.49 & 53.08 & 51.06 & 54.43 & 51.26 & 52.89 & 49.79 & 54.37 & 52.55 & 1.71 & 0.03 \\
\hline $\begin{array}{l}\text { operating } \\
\text { profit margin }\end{array}$ & 39.73 & 40.33 & 35.71 & 39.48 & 45.82 & 41.39 & 42.25 & 97.42 & 43.27 & 47.27 & 19.01 & 0.40 \\
\hline $\begin{array}{l}\text { Net profit } \\
\text { margin }\end{array}$ & 28.43 & 33.43 & 29.97 & 23.34 & 27.75 & 27.71 & 35.89 & 98.99 & 32.72 & 37.58 & 23.33 & 0.62 \\
\hline $\begin{array}{l}\text { Returns on } \\
\text { assets }\end{array}$ & 14.95 & 10.97 & 6.29 & 6.54 & 8.51 & 8.42 & 7.58 & 15.59 & 6.87 & 9.52 & 3.55 & 0.37 \\
\hline $\begin{array}{l}\text { Returns on } \\
\text { equity }\end{array}$ & 27.05 & 16.68 & 15.17 & 18.99 & 13.89 & 11.94 & 8.05 & 18.37 & 8.12 & 15.36 & 5.92 & 0.39 \\
\hline
\end{tabular}

Source: - annual reports of SPL for the years from 2004 to 2012 and computations have been made by the researchers

Table- 4 shows that the average gross profit margin was $52.55 \%$ which was higher than the standard norm of $20 \%$ to $30 \%$ (Abhijit et.al. 2000). It indicates favorable purchasing and mark up policies and proper management to generate sales volume. The average operating ratio of SPL was $47.27 \%$ in the study period which indicates the overall efficiency of its' is satisfactory. In view of this, SPL on average net profit ratio was $37.58 \%$ which was above the standard of $5 \%$ to $10 \%$ (Mandal, 1998).

This indicates that SPL was able to achieve satisfactory return on owner's equity and had a very high efficiency position. The average rate of return on assets for the SPL was $9.52 \%$. This average was below the standard of 10\%-12\%( khan and Jain, 2004). This lower ratio indicates the assets were not being properly utilized during the study period. The average return on equity ratio was $15.36 \%$ which was higher than the standard norm of $10 \%$ to $15 \%$ ( Khan and Jain, 2004). It implies the maximum return available for the shareholders and satisfactory position of use shareholders investment. 


\subsection{Analysis of productivity of SPL:}

Productivity is the ratio of output to input. The analysis of productivity provides better insight in to the efficiency and effectiveness of scare and valuable resource utilization of an entity. The higher the productivity; the lower is the cost because of increase in the volume of output. Lower cost increases revenue and profit. The following table shows the position in this regard:

Table-5 Productivity ratios of SPL during the year 2004 to 2012

\begin{tabular}{|c|c|c|c|c|c|c|c|c|c|c|c|c|}
\hline & 2004 & 2005 & 2006 & 2007 & 2008 & 2009 & 2010 & 2011 & 2012 & Mean & SD & $\mathrm{CV}$ \\
\hline Sales per & 18262 & 19661 & 22050 & 433496 & 655769 & 64107 & 6203 & 59536 & 793517 & 48214 & 23084 & \\
\hline employee & 76 & 97 & 78 & 7 & 0 & 88 & 198 & 92 & 6 & 51 & 80 & 0.48 \\
\hline Net profit per & 51927 & 65738 & 66076 & 101168 & 181985 & 17764 & 2226 & 58935 & 259672 & 19068 & 16709 & \\
\hline employee & 4 & 4 & 2 & 4 & 6 & 17 & 205 & 46 & 1 & 72 & 59 & 0.88 \\
\hline Asset per & 34730 & 59933 & 10500 & 154629 & 213797 & 21097 & 2935 & 37814 & 378144 & 20321 & 12770 & \\
\hline employee & 84 & 32 & 736 & 77 & 34 & 902 & 7911 & 423 & 23 & 614 & 093 & 0.63 \\
\hline $\begin{array}{l}\text { Total income } \\
\text { to expense } \\
\text { ratio }\end{array}$ & 2.20 & 2.43 & 2.17 & 1.83 & 2.01 & 2.17 & 3.08 & 6.97 & 2.50 & 2.82 & 1.60 & 0.57 \\
\hline
\end{tabular}

Source: - annual reports of SPL for the years from 2004 to 2012 and computations have been made by the Researchers.

Table-5 shows the position of productivity ratio of SPL during the period of 2004 to 2012. It is obvious that the per employee revenue, net profit and asset position increases which shows the positive sign of productivity of SPL. In case to total income to expense ratio the average position was 2.82 which indicates satisfactory productivity position of SPL because it was about 3 times greater than the total expenses.

\section{Performance Measurement Using Balance Scorecard:}

Balanced Scorecard has been defined "as a set of measures that gives top managers a fast but comprehensive view of the business, combining in a single report the disparate elements of a company's competitive agenda while attempting to prevent sub-optimization by managers as they must consider all of their organization's significant performance areas together"(Kaplan and Norton,1992).

The balanced scorecard allows managers to look at the business from four important Perspectives. It provides answers to four basic questions:

1. How do customers see us? (Customer perspective)

2. What must we excel at? (Internal business perspective)

3. Can we continue to improve and create value? (Innovation and learning perspective)

4. How do we look to shareholders? (Financial perspective)

The balanced scorecard includes four key elements like Customer, Internal, Innovation and financial perspective which is shown in the following diagram:

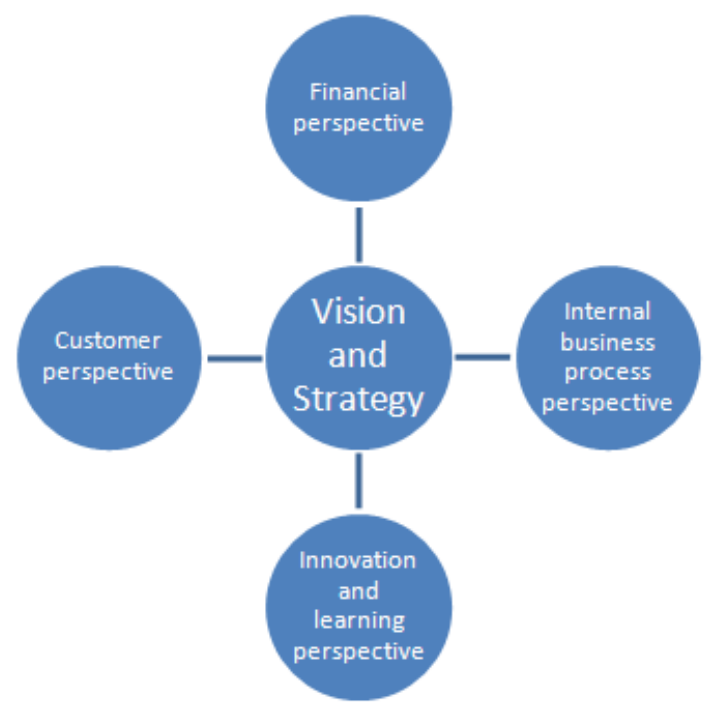

Figure: The Four Perspective of Balanced Score Card

Now we will try to enumerate SPL's balanced scorecard in terms of the four perspectives as follows: 


\subsection{Customer Perspective:}

The customer perspective will help the company address the important concerns of the customers and build continued patronage. SPL is the first Bangladeshi Independent Power Producer (IPP) in Bangladesh in private sector providing power to national grid. Some of the specific measures as follows:

1. Considering the immense opportunities, the company is striving to establish more power plants around the country. The fast-growing company has set a mission to expand the company with a power generation capacity to the tune of $1000 \mathrm{MW}$, which is a modest $20 \%$ of the electricity requirement in Bangladesh.

2. Company has established business relationship with some direct customers/industries.

3. SPL ensures quality \& uninterrupted delivery of electricity.

\subsection{Internal Business Perspective}

The Internal Business perspective aims at identification and improvement of critical internal business processes that yield competitive edge and result in greater customer satisfaction. Some of the measures under the internal perspective are as follows:

1. SPL has developed Multi-channel of power plant like- Ashulia Power Plant, Narsingdi Power Plant,Comilla Power Plant, Ullapara Power Plant, Maona Power Plant, Jangalia Power Plant, Rupganj Power Plant, Madanganj Power Plant

2. Employee motivation and training, colleague reward system based on their performances.

3. Staff grading and promotion, training and development through Dhaka stock exchange, engineering staff college, ICMAB on regular basis for its work force.

4. On environmental issues, Company gives high priority to protecting the environment and ensures humble efforts in this regard include extensive number of sapling plantation in the Company's power plants and neighboring places. Company's state-of-the art power plants comply with the requirements of relevant environmental regulatory bodies. Thus these plants emit relatively less pollutants to the environment. Moreover, SPL has already taken initiatives for ISO14001: 2004 - Environmental Management System (EMS) implementation and certification, which is expected to be completed by next year.

\subsection{Innovation and Learning Perspective}

Innovation has become a key driver in the knowledge economy. Competing globally demands an ability to innovate continually and bring about value enhancements in internal business Processes, external product markets.

1. Summit Power Limited patronizes a number of non-governmental organizations (NGOs) as well as carries out social and humanitarian activities on its own as a part of their social responsibility projects.

2. Over the last 11 years to promote an active life amongst the underprivileged, Summit Group has been organizing a golf tournament for them. By organizing the Professional-Amateur golf tournaments, Summit Group has provided a platform for the underprivileged golfers to enhance their skills and expose their talents at national and international levels.

3. The NGOs and government organizations that receive the support of Summit Group are: Friendship, SEID Trust, Siraj- Khaleda Memorial Hospital in Dhaka Cantonment, Others

4. Summit Power Limited is also involved with the Prothom-Alo Trust Board. This trust is involved in many social activities like sponsoring books to community schools \& colleges and plantation programs for the people of the community.

5. Summit believes in the eagerness, strength and compassion amongst the youth and aims to boost up the spirit within the Bangladeshi youth. To inspire them, we support and sponsor North Alpine Club Bangladesh - NACB 6. SPL as part of their corporate responsibility is assisting SEID Trust to improve the condition of children with autism, intellectual \& multiple disabilities since 2009

\section{Testing financial soundness of Sample Company}

After analyzing profitability, liquidity, activity and solvency of SPL, now it is necessary to determine the financial health of a company during the study period. For determining a company's financial health and bankruptcy risk, the Altman Z score model (Multivariate Discriminate analysis model) considered as a release tools. The model find out the $\mathrm{Z}$ score value and on that basis the enterprise will be classified as good, sick and mixed.

Table-6

\begin{tabular}{|l|l|l|l|l|l|l|l|l|l|l|}
\hline Year & 2004 & 2005 & 2006 & 2007 & 2008 & 2009 & 2010 & 2011 & 2012 & Average \\
\hline Z-Score & 1.58 & 2.29 & 0.39 & 0.71 & 2.30 & 3.37 & 3.70 & 5.68 & 8.56 & 3.18 \\
\hline
\end{tabular}

Source: - annual reports of SPL for the years from 2004 to 2012 and computations have been made by the researchers 
Table- 6 shows the average $\mathrm{Z}$ score stood at 3.18 which is upper than the standard norm of 2.675 . It indicates Summit Power Limited was in safe zone from the risk of bankruptcy and its financial position was sound. But it should be noted that $\mathrm{Z}$ score was determined by Prof. Altman to predict the bankrupt and non bankrupt position of firms in the American context that cannot be logically taken as standard in context of Bangladesh yet it is taken as guide line.

\section{Policy implications for the improvement of performance of SPL:}

The study suggests the following policy implications for SPL:

a) The cost of goods sold of SPL constitutes about $48 \%$ of total revenue which indicates higher margin of profit. SPL has been suffering from lower margin due to the dual administration impact. So for better performance SPL should have independence in making their own decision.

b) The pricing rules should be practical and flexible so that SPL independently run the business.

c) To improve productivity SPL should increase their revenue.

d) For sustainability in the long run SPL should invest more money in Research and Development.

e) SPL should control the operating expenses like administrative, selling and distribution expenses to increase the operating profit.

f) Government might relax the tax burden for SPL to increase the financial health of SPL.

g) For increasing the revenue SPL might use intensive strategic marketing programs for the long term sustainability of SPL.

h) Efficiency should be developed for proper financial management techniques of SPL.

\section{Concluding remarks:}

The Current study on SPL has been taken to critically evaluate the operational performance during the period 2004-2012. The study found that overall operational performance of the selected company in terms of asset management and long term solvency was satisfactory level. In case of liquidity, on a average SPL has a strong position to pay its most immediate liquidity. In case of profitability SPL was able to achieve satisfactory return on owner's equity and had a very high efficiency position. The average rate of return on assets for the SPL was 9.52\%. This average was below the standard of 10\%-12\%( khan and Jain, 2004). This lower ratio indicates the assets were not being properly utilized during the study period. The average return on equity ratio was $15.36 \%$ which was higher than the standard norm of $10 \%$ to $15 \%$ ( Khan and Jain, 2004).It is obvious that the per employee revenue, net profit and asset position increases which shows the positive sign of productivity of SPL. The study also found that non financial performances in case of customer perspective, internal business perceptive and growth and innovation perspective, SPL achieved their target to a greater extent. Discussion made so far lead us to conclude that further research might be taken to explore the performance evaluation of SPL and current study will act as a guideline in this regard.

\section{References:}

[1]. Abhijit,B,Mamun,M.Z and Nazrul, I (2000), "performance of the nationalized General insurance Company of Bangladesh", Bank Parikrama, Vol xxv, No.4, Dhaka, BIBM, December, p.28.

[2]. Benerjee, B(1984), "Financial Planning and Management Accounting”, the world press). (Pvt)., Calcutta, 2 ${ }^{\text {nd }}$ edition,p.565.(The figure of this debt equity ratio is the average of seven years data from 1974-75 to 1980-81.The data were quoted by the author from the reserve bank of India

[3]. Bhattacharyya, S.K,Roy, S.K.(1999), "Management Accounting: Incorporating Accounting theory", NewDelhi: S, Chand \& Company Ltd, p.349.

[4]. Bhunia, Amalendu. Mukhuti, Sri.Somnath \& Roy, Sri. Gautam (2011), "Financial Performance Analysis-A Case Study", Current Research Journal of Social Sciences 3(3): 269-275.

[5]. Hoque,A.K M.J.(1987), “ project Appraisal Practices in the Development Financing Institutions Of Bangladesh”, The Dhaka University Studies, Part C, Volume, viii, No.2, December,p.146.

[6]. Hoque,M.J.(1984), "Financial planning and Control in public sector industries in Bangladesh", Chittagong University studied (commerce), vol-1,p.38

[7]. Jahur, Mohammad Saleh \& Uddin, Mohammad Mohi (1995), "Measurement of Operational Performance through ratio analysis- A case study of Usmania Glass Sheet Factory Ltd. Chittagong", Chittagong University studied (commerce), vol 11, pp. 245-255.

[8]. Jahur, Mohammad Saleh \& parveen, jannat ara, (1996), “An analysis of financial performance Of public enterprises- A case study of Chittagong Still Mills Ltd.”, Chittagong University studied (commerce), vol 12, pp.173-184.

[9]. Khan,M.Y \& Jain,P.k. Financial Management, Tata Mc.Graw-Hill Publishing company limited,new Delhi,p.179.

[10]. Kaplan, R.S. and Norton, D.P. (1992)'The balanced scorecard-measures that drive Performance', Harvard Business Review, 70, (jan-feb): 71-9.

[11]. Moshin, M.N (1970), "Financial Planning and Control”, Vikas Publishing House Pvt. Ltd, New Delhi, p.174.

[12]. Pandey,I.M.(1979), Financial management, Vikas Publishing House Pvt. Ltd, New Delhi, pp.109-116 This academic article was published by The International Institute for Science, Technology and Education (IISTE). The IISTE is a pioneer in the Open Access Publishing service based in the U.S. and Europe. 